\title{
Microbial and enzymatic activity as influenced by existing cropping pattern in the soils of Ganges floodplain
}

\author{
Mohammad Zaber Hossain, Md. Rezaul Karim, Bina Rani Majumder \& Falguni Akter*
}

Soil, Water and Environment Discipline, Khulna University, Bangladesh

\section{Article history}

Received: 04 April 2019

Accepted: 21 June 2019

Published: 17 July 2019

\section{Publisher}

Horizon e-Publishing Group

\author{
*Correspondence \\ Falguni Akter \\ \. falgunissku@gmail.com
}

\begin{abstract}
Effect of multi cropping (Potato-Jute-Sweetgourd-T.Aman, Sweet gourd-Brinjal-Jute, Cauliflower-Radish-Lentil-Basil, Jute-Lentil-Mustard-Wheat and Sweetgourd-Turnip, designated as P-J-S-T, S-B-J, C-R-L-B, J-L-M-W and S-T, respectively) and mono cropping systems (orchard of Lychee, Teak, Turmeric and Banana) on microbial and enzymatic activity of Ganges floodplain soil was investigated. Organic carbon, microbial biomass carbon (MBC), microbial biomass nitrogen (MBN), soil respiration, total nitrogen and urease activity (UA) of the soils were examined. Upon examination it was observed that soils under mono cropping pattern (Lychee, Teak, and Banana) showed significantly $(\mathrm{p} \leq 0.05)$ higher $\mathrm{MBC}, \mathrm{MBN}$ and UA than those under multi cropping pattern. Highest values of MBC and UA found in teak plant were 95.44 milligram/kilogram (mgkg $\left.{ }^{-1}\right)$ and $6.51 \mu \mathrm{g} \mathrm{N}$ released $\mathrm{g}^{-1} \mathrm{day}^{-1}$ respectively while for multi cropping pattern the respective values were 37.52 mgkg- $^{1}$ and $2.23 \mu \mathrm{g} \mathrm{N}$ released $\mathrm{g}^{-1}$ day $^{-1}$ found in S-T and J-L-M-W cropping pattern. The highest MBN (12.70 $\left.\mathrm{mgkg}^{-1}\right)$ was obtained in soil where lychee was practiced. Multi cropping soil showed significantly $(\mathrm{p} \leq 0.05)$ higher respiration rate than mono cropping soil and the highest rate was found $508.75 \mathrm{mg} \mathrm{CO}_{2} \mathrm{~g}^{-1} \mathrm{day}^{-1} \mathrm{in} \mathrm{J-M-L-}$ $\mathrm{W}$ cropping pattern. Turmeric showed the lowest respiration rate $\left(120.75 \mathrm{mg} \mathrm{CO}_{2} \mathrm{~g}^{-1} \mathrm{day}\right.$ ${ }^{1}$ ) among the cropping pattern studied. Both MBC and UA showed positively significant relation with soil organic carbon, and total $\mathrm{N}$ at $0.01 \%$ level. High microbial and enzymatic activity of mono cropping soil represent combined effect of vegetation and low tillage practices in soil.
\end{abstract}

Keywords: Cropping pattern; microbial biomass; urease activity; respiration.

Citation: Hossain MZ, Karim MR, Majumder BR, Akter F. Microbial and enzymatic activity as influenced by existing cropping pattern in the soils of Ganges floodplain. Plant Science Today 2019; 6(3):309-314. https://doi.org/10.14719/pst.2019.6.3.545

Copyright: (C) Hossain et al (2019). This is an open-access article distributed under the terms of the Creative Commons Attribution License, which permits unrestricted use, distribution, and reproduction in any medium, provided the original author and source are credited (https://creativecommons.org/licenses/by/4.0/).

Indexing: Plant Science Today is covered by Scopus,Web of Science, BIOSIS Previews, ESCI, CAS, AGRIS, CABI, Google Scholar, etc. Full list at http://www.plantsciencetoday.online

\section{Introduction}

With the increasing emphasis on sustainable agriculture and soil quality, it is important to determine the effect of different crop management practices on soil organic matter. The soil organic matter fractions that are considered important include microbial biomass carbon, soil organic carbon and nitrogen. Microbial biomass carbon is more responsive to cultural treatments than total soil organic matter (1). Because of its high turnover 
rate, microbial biomass carbon could respond more rapidly to change of soil environment than soil organic matter (2). Measurement of the size of soil microbial biomass couldn't indicate microbial activity. Microbial activities include basal respiration rate and the activities of general enzymes such as alkaline phosphatase and urease. Soil enzyme activities are often used as indices of microbial activity and catalyze many important soil processes such as soil organic matter decomposition, production of mineral nutrient forms as well as flow of various elements of the biochemical cycle. Determination of enzyme activity is essential to characterize the metabolic potential, soil fertility and quality that are useful in soil assessment. There is a strong relationship between soil organic matter content and enzyme activities. Both parameters are influenced by cultivation practices. According to Dahm and Burns the chemical composition of higher plants affects soil enzyme activities which may considerably differ between the genera, species and also varieties $(3,4)$. In the soil, urease activity is closely related to organic matter (5). Krämer and Green observed that tree stands stimulate enzyme activity in soils as a result of increasing biomass of microorganisms producing enzymes (6). Urease occurred in the soil due to the addition of organic and inorganic manure (8). Therefore soil microbial biomass, microbial respiration, the metabolic quotient $\left(\mathrm{qCO}_{2}\right)$ and soil enzymatic activity can be utilized as indicator for changes in soil quality produced by agricultural management practices (9). The aim of this research work is to assess the soil microbial and enzymatic activities of the bench mark soil series of Bangladesh with existing cropping pattern of the physiographic unit Ganges floodplain.

\section{Materials and Methods}

This study considered different sites of 'Ghona' village of Jessore sodor Upazila under Jessore district as the study site. Soil samples were collected at a depth of $0-15 \mathrm{~cm}$ from the field where multi and mono cropping systems were practiced in the study area. Nine cropping patterns were found in this multi and mono cropping field (Table 1).

Soil organic carbon was determined by Walkley and Black wet oxidation method as described by Piper (10). Soil nitrogen was determined by colorimetric method as suggested

Table 1. Soil characteristics with different cropping pattern

\begin{tabular}{lllllll}
\hline Cropping pattern & Crop Sequence & Notation & $\mathrm{pH}$ & $\mathrm{EC}\left(\mathrm{dSm}^{-1}\right)$ & Moisture (\%) & Texture \\
\cline { 2 - 7 } Multi cropping & Potato-Jute-Sweetgourd-T.Aman & P-J-S-T & 7.10 & 1.45 & 23.15 & SiCL \\
\cline { 2 - 7 } & Sweetgourd-Brinjal-Jute & S-B-J & 6.23 & 2.10 & 13.83 & SL \\
\cline { 2 - 7 } & Cauliflower-Radish-Lentil-Basil & C-R-L-B & 7.19 & 3.80 & 28.37 & SiCL \\
\cline { 2 - 7 } & Jute-Lentil-Mustard-Wheat & J-L-M-W & 7.49 & 0.78 & 12.11 & CL \\
\cline { 2 - 7 } & Sweetgourd-Turnip & S-T & 7.30 & 0.78 & 17.86 & SC \\
\hline Mono cropping & Orchard (Lychee) & -- & 6.78 & 1.45 & 14.11 & SiCL \\
\cline { 2 - 6 } & Orchard (Teak) & -- & 7.38 & 0.78 & 29.37 & SiCL \\
\hline & Turmeric & -- & 7.56 & 0.78 & 20.77 & SCL \\
\hline
\end{tabular}

Table 2. Influence of cropping pattern on organic carbon, microbial biomass carbon, total nitrogen, microbial nitrogen and $\mathrm{C} / \mathrm{N}$ ratio of soil

\begin{tabular}{lllllll}
\hline \multicolumn{1}{c}{$\begin{array}{c}\text { Cropping } \\
\text { pattern }\end{array}$} & Notation & Organic C (\%) & MBC $\left(\mathrm{mgkg}^{-1}\right)$ & Total N (\%) & MBN $\left(\mathrm{mgkg}^{-1}\right)$ & $\mathrm{C} / \mathrm{N}$ \\
\hline $\begin{array}{l}\text { Multi } \\
\text { cropping }\end{array}$ & P-J-S-T & $0.87 \mathrm{~d} \pm 0.06$ & $36.96 \mathrm{c} \pm 3.07$ & $0.041 \mathrm{a} \pm 0.004$ & $2.20 \mathrm{e} \pm 0.28$ & $21.22 \mathrm{~cd} \pm 0.55$ \\
\cline { 2 - 7 } & S-B-J & $0.94 \mathrm{~cd} \pm 0.02$ & $25.80 \mathrm{e} \pm 1.76$ & $0.043 \mathrm{a} \pm 0.003$ & $6.30 \mathrm{~b} \pm 0.32$ & $21.86 \mathrm{~cd} \pm 1.67$ \\
\cline { 2 - 7 } & C-R-L-B & $0.84 \mathrm{~d} \pm 0.01$ & $25.28 \mathrm{e} \pm 1.84$ & $0.047 \mathrm{a} \pm 0.005$ & $4.30 \mathrm{c} \pm 0.42$ & $17.87 \mathrm{~d} \pm 2.19$ \\
\cline { 2 - 7 } & J-L-M-W & $0.89 \mathrm{~d} \pm 0.03$ & $31.68 \mathrm{~d} \pm 1.95$ & $0.048 \mathrm{a} \pm 0.004$ & $2.80 \mathrm{de} \pm 0.16$ & $18.54 \mathrm{~cd} \pm 2.19$ \\
\hline $\begin{array}{l}\text { Mono } \\
\text { cropping }\end{array}$ & S-T & $0.85 \mathrm{~d} \pm 0.03$ & $37.52 \mathrm{c} \pm 0.58$ & $0.039 \mathrm{a} \pm 0.003$ & $3.10 \mathrm{~d} \pm 0.21$ & $21.79 \mathrm{~cd} \pm 2.18$ \\
\cline { 2 - 7 } & Lychee & $1.43 \mathrm{~b} \pm 0.09$ & $73.68 \mathrm{~b} \pm 1.23$ & $0.049 \mathrm{a} \pm 0.005$ & $12.70 \mathrm{a} \pm 0.62$ & $29.18 \mathrm{ab} \pm 2.77$ \\
\hline & Teak & $1.72 \mathrm{a} \pm 0.09$ & $95.44 \mathrm{a} \pm 0.72$ & $0.053 \mathrm{a} \pm 0.288$ & $3.00 \mathrm{de} \pm 0.02$ & $32.45 \mathrm{a} \pm 4.10$ \\
\hline
\end{tabular}

activity can be used as an indicator of soil quality and changes under the effect of soil use. Ureases are involved in releasing inorganic nitrogen in the nitrogen cycle (7). Soil respiration, metabolic quotient and soil enzymatic activity are adequate indicators of microbial activity and modifications by Baethgen and Alley (11). Soil microbial biomass carbon and nitrogen were determined by the fumigation - extraction procedure as suggested by Vance et al. (12). Soil urease activity was measured as described by Tabatabai and Bremner (13). Soil respiration $\left(\mathrm{CO}_{2}\right)$ was determined by the short 
term volumetric procedure as described by Anderson and Ingram (14). Microbial quotient was calculated as the ratio of soil microbial carbon to soil organic carbon and expressed as percent (15). Soil pH (soil: water ratio of 1: 2.5) as suggested by Jackson (16), electrical conductivity (EC) (17), moisture was determined by oven drying method (18) and the particle size distribution by the hydrometer method (19). The means and standard errors were calculated using Excel (Microsoft Office 2007). Analysis of variance was performed using Minitab's statistical software (version 17.0).

\section{Results and Discussion}

The characteristics of the nine cropping pattern soil are described in Table 1 . The soils used were varying in texture with slightly acid to slightly alkaline in nature (pH: 6.23-7.56). EC ranges from $0.78-3.80 \mathrm{dSm}^{-1}$ which belongs to non-saline to very slightly saline soil. Soil moisture content varies from $9.83-29.37 \%$.

Table 3. Effect of cropping pattern on soil respiration and microbial quotient of soil.

\begin{tabular}{llll}
\hline $\begin{array}{l}\text { Cropping } \\
\text { pattern }\end{array}$ & Notation & $\begin{array}{l}\text { Soil respiration } \\
\left(\mathrm{mg} \mathrm{CO}_{2} \mathrm{~g}^{-1} \mathrm{day}^{-1}\right)\end{array}$ & $\begin{array}{l}\text { Microbial } \\
\text { Quotient }(\%)\end{array}$ \\
\hline $\begin{array}{l}\text { Multi } \\
\text { cropping }\end{array}$ & P-J-S-T & $178.75 \mathrm{f} \pm 1.54$ & $0.42 \mathrm{~b}$ \\
\cline { 2 - 4 } & S-B-J & $123.75 \mathrm{~g} \pm 5.21$ & $0.27 \mathrm{c}$ \\
\cline { 2 - 4 } & C-R-L-B & $343.75 \mathrm{e} \pm 8.03$ & $0.30 \mathrm{c}$ \\
\cline { 2 - 4 } & J-L-M-W & $508.75 \mathrm{a} \pm 1.54$ & $0.36 \mathrm{c}$ \\
\hline $\begin{array}{l}\text { Mono } \\
\text { cropping }\end{array}$ & S-T & $453.75 \mathrm{~b} \pm 4.88$ & $0.44 \mathrm{~b}$ \\
\cline { 2 - 4 } & Lychee & $453.75 \mathrm{~b} \pm 1.49$ & $0.52 \mathrm{a}$ \\
\hline & Teak & $433.75 \mathrm{c} \pm 3.61$ & $0.55 \mathrm{a}$ \\
\hline & Turmeric & $120.75 \mathrm{~g} \pm 1.27$ & $0.28 \mathrm{c}$ \\
\hline
\end{tabular}

Organic $\mathrm{C}$ and microbial biomass carbon (MBC) of different cropping pattern soil is summarized in Table 2. Organic $\mathrm{C}$ and microbial biomass carbon showed variations among the studied cropping pattern soil. Soils with mono cropping pattern showed significantly $(p \leq 0.05)$ higher organic $C$ and $\mathrm{MBC}$ than that of multi cropping pattern. In mono crop, teak soil showed the highest MBC (95.44 $\mathrm{mg} \mathrm{kg}^{-1}$ ) that did not differed significantly with banana soil and turmeric soil showed the lowest MBC $(25.28 \mathrm{mg} \mathrm{kg}$ $\left.{ }^{1}\right)$. MBC content varied significantly in multi cropping soil and soil with (S-T) crop sequence showed the highest (37.52 $\mathrm{mg} \mathrm{kg}^{-1}$ ) MBC and (C-R-LB) crop sequence showed the lowest $(25.28 \mathrm{mg} \mathrm{kg}$ $\left.{ }^{1}\right)$. The higher MBC content in mono crop soil may be due to the cultivation of broad leaved plants in which more microorganisms are available for the decomposition of plant materials. Whereas the coarse texture in turmeric soil was responsible for lower content of MBC among the mono crop soil.

Highest organic carbon recorded in mono cropping indicates high level of organic inputs and low disturbances from tillage practice which were significantly different from multi cropping soil.
The highest carbon content (1.72\%) was found in teak cultivated soil which had significantly different carbon values than that of the other soil. Carbon content did not vary among the multi cropping soil. Omay et al. observed similar result in which they found that crop rotations that include high residue producing crops and addition of fertilizer increased soil organic carbon and nitrogen (20). Cong et al. found that decomposition rate was higher in multi cropping soils than mono crop soils (21). Liu et al. observed a reverse trend of increasing organic carbon in different cropping pattern (22). They concluded that cultivation and tillage can reduce soil organic carbon (SOC) content and lead to soil deterioration. The microbial nitrogen was highest $\left(12.70 \mathrm{mg} \mathrm{kg}^{-1}\right)$ in mono crop soil under lychee plants which significantly $(p \leq 0.05)$ differ from the other cropping systems practised (Table 2). The distribution of soil organic matter in different cropping pattern as expressed by the $\mathrm{C} / \mathrm{N}$ ratio found higher in mono cropping than those obtained in multi cropping soil.

Soil respiration varied significantly among the cropping pattern soil studied (Table 3 ). The highest respiration rate $\left(508.75 \mathrm{mg} \mathrm{CO}_{2} \mathrm{~g}^{-1}\right.$ day $\left.^{-1}\right)$ was observed in J-L-M-W cropping pattern soil and the lowest value was found in turmeric $(120.75 \mathrm{mg}$ $\mathrm{CO}_{2} \mathrm{~g}^{-1}$ day $\left.^{-1}\right)$ soil. Generally, higher residue production was accompanied by higher $\mathrm{CO}_{2}$ emission rate. Higher respiration rate for J-L-M-W cropping pattern was associated with the biomass of winter wheat root and stubble biomass. Chen and Huang showed that higher residue production was in accordance with higher soil respiration rate for the maize planted farmland (23).

Amount of microbial biomass carbon derived from soil organic carbon has been determined (Table 3). Mono crop soil showed the highest $(0.62 \%, 0.55 \%$ and $0.52 \%$ for banana, teak and lychee respectively) contribution of carbon in soil through microbial biomass carbon than multi crop soil. In this study microbial biomass carbon found significantly lower in multi-cropping soil than mono crop (Table 2). The greater proportion of the active pools of carbon i.e. microbial carbon in the cropping soil suggests faster soil organic carbon turn over compared with the multi cropping soil. This is supported by higher percentages of microbial carbon for the mono cropping soil. Faster turnover of soil organic carbon means greater carbon availability. Various tillage practices may be the reason for lowering of microbial carbon in multi-cropping soil. Kabiri et al. found that soils under reduced tillage (RT) systems had higher microbial biomass and enzyme activity, but the increase of less metabolically active microbes; most likely therefore of changes in the microbial population composition and lower microbial turnover rate (24). Underneath no-tillage systems, total organic $\mathrm{C}$ and $\mathrm{N}$ of microbial biomass were significantly higher than 
conventional tillage $(25,26)$. Franzluebbers also observed similar result where they found soil microbial biomass carbon was an average of $65 \%$ greater under no tillage than conventional tillage at the $0-50 \mathrm{~mm}$ depth (27).

Urease activity of different cropping pattern soil is summarized in Fig. 1. The highest urease activity $\left(6.51 \mu \mathrm{g} \mathrm{N}\right.$ released $\mathrm{g}^{-1}$ soil day $\left.{ }^{-1}\right)$ was observed in mono crop soil covered with teak and the lowest $\left(0.160 \mu \mathrm{g} \mathrm{N}\right.$ released $\mathrm{g}^{-1}$ soil day $\left.{ }^{-1}\right)$ was found in multi crop soil at S-B-J cropping pattern. Mono crop soil showed significantly $(p \leq 0.05)$ different urease activity and turmeric showed the lowest activity among the mono crop soil examined. This may be due to the soil where turmeric was practiced. Banana and teak were broad leaved plants and lychee produced higher biomass for which urease activity found higher in these mono crop soils.

Orchard (banana) $\left(6.332 \mu \mathrm{g} \mathrm{N}\right.$ released $\mathrm{g}^{-1}$ soil day $\left.{ }^{-1}\right)$ and orchard (lychee) $(6.143 \mu \mathrm{g} N$ released
This finding confirmed the findings of Shresta et al. (28) who observed increased biomass content with manure application. Goyal et al. (29) reported that the amount of soil organic matter and mineralizable $\mathrm{C}$ and $\mathrm{N}$ were highest in plots receiving organic treatments.

The type of cropping pattern significantly affected urease activity. The highest activity for the enzyme assayed was observed where the orchard rotation was maintained. The lowest activity was observed in S-B-J rotation. The relative effect of the various rotations on urease activity at the surface soil varies considerably. However, the magnitude of the rotation effect was greater. Urease activity in the orchard was approximately forty times greater than in S-B-J pattern. With the exception of the J-L-M-W pattern which showed moderate activity of the urease in soil. Urease activity in the J-L-M-W rotation was approximately fifteen times greater than in S-B-J rotation. One of the major reasons for decreasing the urease

\section{UA}

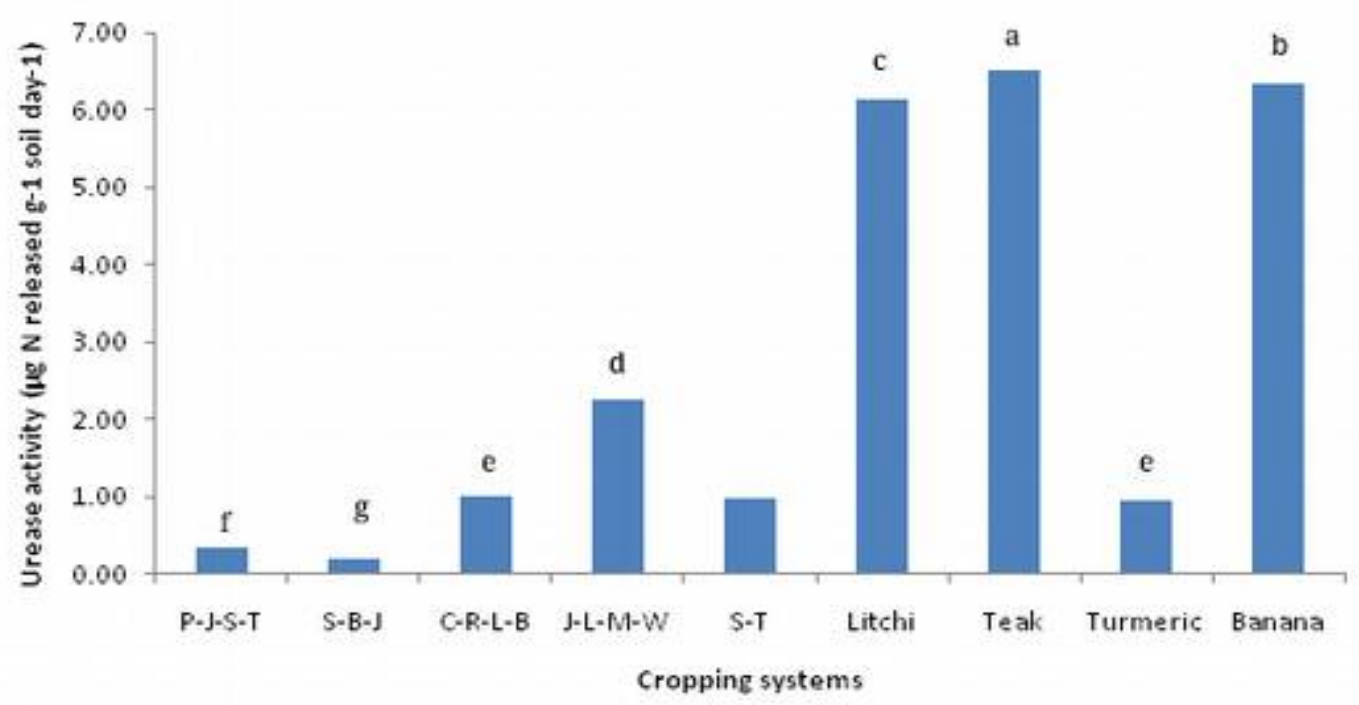

Fig. 1. Urease activity of soils of different cropping systems

$\mathrm{g}^{-1}$ soil day ${ }^{-1}$ ) cropping pattern with orchard (teak) showed higher urease activity than other types of cropping pattern studied. In cropping pattern of JL-M-W soil urease activity was $2.234 \mu \mathrm{g} N$ released $\mathrm{g}^{-1}$ soil day ${ }^{-1}$. On the other hand, C-R-L-B $(0.981 \mu \mathrm{g} \mathrm{N}$ released $\mathrm{g}^{-1}$ soil day $\left.{ }^{-1}\right)$, turmeric $(0.942 \mu \mathrm{g} N$ released $\mathrm{g}^{-1}$ soil day $\left.{ }^{-1}\right)$ and S-T $(0.968 \mu \mathrm{g} N$ released $\mathrm{g}^{-1}$ soil day ${ }^{-1}$ ) cropping pattern soil showed more or less equal urease activity. Among the multi crop soil J-L-M-W showed higher activity due to the crop used.

Data analysis regarding microbial nitrogen (MBN) revealed that the highest MBN was found for lychee $\left(12.70 \mathrm{mg} \mathrm{kg}^{-1}\right)$ of mono crop soil and SB-J $\left(6.30 \mathrm{mg} \mathrm{kg}^{-1}\right)$ of multi crop soil. The addition of organic and inorganic fertilizers increased the MBN in both the cropping pattern soil studied. activity in multicropping pattern than in orchard is type of cultivation practices utilized. At sites where no-till was imposed following years of conventional tillage, the enzyme activities of the surface layer was found to increase. Kennedi and Smith observed similar result (30). C-R-L-B rotation and J-L-M-W rotation had common crop of lentil, but both rotation showed different urease activity. One of the major reasons for higher urease activity in J-L-M-W rotation was inclusion of wheat in the rotation. In J-L-M-W rotation more organic residue was added for leaf falling from wheat plant. As a result microbial activity was high, so enzyme activity was also high. Miller and Dick reported that enzymes activities were found to be significantly higher for a legume-vegetable rotation than for the traditional vegetable rotation (31). 


\section{Correlation analysis}

The correlation analysis of some selected variables of the mono cropping soil is represented in the Table 4.

The data revealed highly significant relationships for all combinations of organic carbon, microbial biomass carbon, urease activity and soil respiration $(\mathrm{p}<0.01)$ except for total nitrogen. This confirms that soil biological communities played a critical role in soil fertility formation and nutrient cycling and they could not only provide plant available nutrients but also accumulate soil organic carbon in mono cropping soil.

Table 4. Correlation matrix for selected variables in the studied soil.

\begin{tabular}{llllll}
\hline & Org C & MBC & Total N & UA & Respiration \\
\hline Org C & -- & & & & \\
\hline MBC & $0.393^{* *}$ & -- & & & \\
\hline Total N & 0.262 & 0.266 & -- & & \\
\hline UA & $0.906^{* *}$ & $0.959^{* *}$ & 0.213 & -- & \\
\hline Respiration & $0.863^{* *}$ & $0.915^{* *}$ & 0.188 & $0.991^{* *}$ & -- \\
\hline
\end{tabular}

\section{Conclusion}

The result showed that cropping pattern was a major determinant for microbial biomass carbon and urease activity in the studied soil. The results of the present study demonstrated the strong relationship of microbial biomass carbon and urease activity in mono cropping soil. The lowest activity was recorded in the soils used for multi cropping that provide significantly less organic matter. Less tillage operation in mono cropping soil may be the triggering factor in having higher microbial biomass carbon and urease activity which are considered as important indicators of changes in soil quality.

\section{Acknowledgement}

The authors acknowledge Khulna University Research Cell of Bangladesh for financing and supporting this study.

\section{Author's contributions}

MZH performed field work, data collection, statistical analysis, manuscript writing, development and interpretation of the results. MRK participated in field work, statistical analyses and result interpretation. BRM participated in field work, statistical analyses and result interpretation. FA participated in result interpretation and in writing manuscript.

\section{Competing interests}

The authors declare that they have no competing interests.

\section{References}

1. Mc Gill WB, Cannon KR, Robertson G, Cook FD. Dynamics of soil microbial biomass and water-soluble organic $C$ in Breton L after 50 years of cropping to two rotations. Canadian Journal of Soil Science 1986; 66(1):1-19. https:// doi.org/10.4141/cjss86-001

2. Powlson DS, Brookes PC, Christensen BT. Measurement of soil microbial biomass provides an early indication of changes in the total soil organic matter due to straw incorporation. Soil Biology and Biochemistry 1987; 19:159-164. https://doi.org/10.1016/0038-0717(87)90076-9

3. Dahm H. Generic composition and physiological and cultural properties of heterotrophic bacteria isolated from soil, rhizosphere and mycorrhizosphere of pine (Pinus sylvestris L.). Acta Microbiologica Polonica 1984; 33(2):147-156.

4. Burns RG. The rhizosphere: microbial and enzymatic gradient and prospects for manipulation. Pedologie 1985; 35(3): 283-295.

5. Alef K, Nannipieri P. Enzyme activities, in: Methods in applied Soil Microbiology and Biochemistry (eds. K. Alef, P. Nannipieri). Academic Press, London, New York: San Francisco; 1995.

6. Krämer S, Green DM. Acid and alkaline phosphatase dynamics and their relationship to soil microclimate in a semiarid woodland. Soil Biology and Biochemistry 2000; 32:179-188.

7. Bandick AK, Dick RP. Field management effects on soil enzyme activities. Soil biology and Biochemistry 1999; 31:1471-1479. 0717(99)00051-6 https://doi.org/10.1016/S0038-

8. Fernandes AR, Mira NP, Vargas RC, Canelhas I, SáCorreia I. Saccharomyces cerevisiae adaptation to weak acids involves the transcription factor Haa1p and Haa1p-regulated genes. Biochemical and biophysical research communications 2005; 337(1):95-103. https://doi.org/10.1016/j.bbrc.2005.09.010

9. Zhang B, He H, Ding X, Zhang X, Zhang X, Yang X, Filley TR. Soil microbial community dynamics over a maize (Zea mays L.) growing season under conventional-and no-tillage practices in a rainfed agroecosystem. Soil and Tillage Research 2012; 124:153-160. https://doi.org/10.1016/j.still.2012.05.011

10. Piper CS. Soil and Plant Analysis The University of Adelaide Press, Adelaide: Australia; 1950.

11. Baethgen WE, Alley MM. A manual colorimetric procedure for measuring ammonium nitrogen in soil and plant Kjeldahl digests. Communication in Soil Science and Plant Analysis 1989; 20(9-10): 961-969. https://doi.org/10.1080/00103628909368129

12. Vance ED, Brookes PC, Jenkinson DS. An extraction method for measuring soil microbial C. Soil Biology and Biochemistry 1987; 19:703-707. https://doi.org/10.1016/0038-0717(87)90052-6

13. Tabatabai MA, Bremner JM. Assay of urease activity in soils. Soil Biology and Biochemistry 1972; 4:479-487. https://doi.org/10.1016/0038-0717(72)90064-8

14. Anderson JM, Ingram JS. Tropical Soil Biology and Fertility: A Handbook of Methods. $2^{\text {nd }}$ ed. Information press, Eynsham: UK; 1993.

15. Anderson JM, Domsch KH. Application of eco physiological quotients ( $\mathrm{qCO}_{2}$ and $\mathrm{qD}$ ) on microbial biomass from soils of different cropping histories. Soil Biology and Biochemistry 1990; 22:251-255. https://doi.org/10.1016/0038-0717(90)90094-G 
16. Jackson ML. Soil Chemical Analysis. Prentice Hall of India Pvt. Ltd.: New Delhi; 1973.

17. USDA (United States Department of Agriculture). Soil Survey Laboratory Manual, soil survey investigation report no. 42, version 4.0, USDA-NRCS, Nebraska: USDA; 2004.

18. Pansu M, Gautheyrou J. Handbook of soil analysis: mineralogical, organic and inorganic methods. Springer Science and Business Media 2007 Apr 18.

19. Day PR. Particle fraction and particle size analysis. In: Black AC, Evans DD, Ensminger LE, White JL, Clark FE, editors. Methods of Soil Analysis, Part I. American Society of Agronomy: Madison 1965. p. 545 - 566.

20. Omay AB, Rice CW, Maddux LD, Gordon WB. Changes in soil microbial and chemical properties under long-term crop rotation and fertilization. Soil Science Society of America Journal 1997; 61:1672-1678. https://doi.org/10.2136/sssaj1997.03615995006100060019x

21. Cong WF, Hoffland E, Li L, Janssen BH, Van der Werf W. Intercropping affects the rate of decomposition of soil organic matter and root litter. Plant and Soil 2015; 391(12):399-411.

22. Liu X, Herbert SJ, Hashemi AM, Zhang X, Ding G. Effects of agricultural management on soil organic matter and carbon transformation - a review. Plant and Soil Environment 2006; 52(12):531-543.

23. Chen S, Huang Y. Soil respiration and $\mathrm{N}_{2} \mathrm{O}$ emission in croplands under different ploughing practices: a case study in south-east China. Australian Journal of Soil Research 2009; https://doi.org/10.1071/SR07225

24. Kabiri V, Raiesi F, Ghazavi MA. Tillage effects on soil microbial biomass, SOM mineralization and enzyme activity in a semi-arid Calcixerepts. Agriculture, Ecosystems \& Environment 2016; 232:73-84. https://doi.org/10.1016/j.agee.2016.07.022

25. Alvear M, Rosas A, Rouanet JL, Borie F. Effects of three soil tillage systems on some biological activities in an Ultisol from southern Chile. Soil and Tillage Research 2005;82(2):195-202. https://doi.org/10.1016/j.still.2004.06.002

26. Jin K, Sleutel S, Buchan D, De Neve S, Cai DX, Gabriels D, Jin JY. Changes of soil enzyme activities under different tillage practices in the Chinese Loess Plateau. Soil and Tillage Research 2009; 104(1):115-20.

27. Franzluebbers AJ. Soil organic matter stratification ratio as an indicator of soil quality. Soil and Tillage Research 2002; 66:95-106. https://doi.org/10.1016/S01671987(02)00018-1

28. Shresta, RK, Lal R, Jacinthe PA, Enhancing carbon and nitrogen sequestration in reclaimed soils through organic amendments and chiseling. Soil Science Society of America Journal 2009; 73:1004-1011.

29. Goyal, S, Sakamoto K, Inubushi L, Kamaewada K, Longterm effects of inorganic fertilization and organic amendments on soil organic matter and soil microbial properties in Andisols. Archives of Agronomy and Soil Science 2006; 52(6):617-625.

30. Kennedi AC, Smith KL. Soil microbial diversity and the sustainability of agricultural soils. Plant and Soil 1995; 170:75-86.

31. Miller M, Dick RP. Thermal stability and activities of soil enzymes as influenced by crop rotations. Soil Biology and Biochemistry 1995; 27:1161-1166. https://doi.org/10.1016/0038-0717(95)00045-G 